Ekspansi: Jurnal Ekonomi, Keuangan, Perbankan dan Akuntansi

ISSN (Online): 2580-7668 ISSN (Print): 2085-5230

Vol. 12, No. 1 (Mei 2020), Hal. 105 - 118

\title{
PENGARUH RISIKO PEMBIAYAAN AKAD MURABAHAH, MUSYARAKAH, DAN MUDHARABAH TERHADAP PROFITABILITAS BPRS DI INDONESIA TAHUN 2011-2019
}

\author{
Silvia Isfiyanti ${ }^{1}$, Rozmita Dewi Yuniarti ${ }^{2}$, Rumaisah Azizah Al Adawiyah ${ }^{3}$ \\ ${ }^{1,2,3}$ Fakultas Pendidikan Ekonomi dan Bisnis, Universitas Pendidikan Indonesia, Bandung, \\ Indonesia \\ Email Korespondensi: rumaisah.azizah@upi.edu
}

\begin{abstract}
This study aims to determine the effect of Murabahah financing risk (NPF), Musyarakah financing risk (NPF), and Mudharabah financing risk (NPF) on the Return on Assets (ROA) of BPRS in Indonesia 2011-2019. The research method used is a quantitative method using multiple linear regression analysis. Partially, it shows the results of the risk of financing the Murabahah contract have a significant and significant effect on ROA in a negative direction, while the risk of financing the Musyarakah contract has no significant effect on ROA in a positive direction, besides that the risk of Mudharabah financing has a significant and significant effect on ROA in a positive direction. The findings of this study add to the research literature and strengthen the theory that the risk of financing will affect the company's ability to generate profits, and produce implications if the risk of financing on the Murabahah, Musyarakah, and Mudharabah contracts increases, the Return on Assets will decrease, so the implementation of risk mitigation or efforts prevention carried out by Islamic banks in minimizing problematic financing must be increased, especially in providing financing facilities to customers.
\end{abstract}

Keywords: Profitability, Financing risk, Non Performing Financing.

Abstrak: Penelitian ini bertujuan untuk mengetahui pengaruh risiko pembiayaan (NPF) Murabahah, risiko pembiayaan (NPF) Musyarakah, dan risiko pembiayaan (NPF) Mudharabah terhadap Return on Asset (ROA) BPRS di Indonesia Tahun 2011-2019. Metode penelitian yang digunakan adalah metode kuantitatif dengan menggunakan analisis regresi linier berganda. Secara parsial menunjukan hasil risiko pembiayaan akad Murabahah berpengaruh dan signifikan terhadap ROA dengan arah yang negatif, sedangkan risiko pembiayaan akad Musyarakah tidak berpengaruh signifikan terhadap ROA dengan arah yang positif, selain itu risiko pembiayaan Mudharabah berpengaruh dan signifikan terhadap ROA dengan arah yang positif. Temuan penelitian ini menambah literatur penelitian dan memperkuat teori bahwa risiko pembiayaan akan mempengaruhi kemampuan perusahaan untuk menghasilkan laba, serta menghasilkan implikasi apabila risiko pembiayaan pada akad Murabahah, Musyarakah, dan Mudharabah mengalami kenaikan maka Return on Asset akan mengalami penurunan, sehingga penerapan mitigasi risiko atau upaya pencegahan yang dilakukan oleh bank syariah dalam meminimalisir pembiayaan bermasalah harus ditingkatkan, terutama dalam pemberian fasilitas pembiayaan kepada nasabah.

Kata Kunci: Profitabilitas, Risiko Kredit Akad Pembiayaan, Non Performing Financing.

DOI: $10.35313 /$ ekspansi.v12i1.1926 


\section{PENDAHULUAN}

Saat ini perekonomian di Indonesia mulai didominasi oleh usaha kecil dan menengah, namun perkembangan tersebut tidak didorong dengan modal usaha yang cukup. Sehingga banyak perbankan yang memanfaatkan momen tersebut, karena peran bank sebagai lembaga keuangan yang dapat menjamin berjalannya aktivitas perekonomian dan kegiatan para pengusaha dalam peminjaman maupun penambahan modal untuk perkembangan usahanya. Salah satu lembaga keuangan tersebut adalah BPRS atau Bank Pembiayaan Rakyat Syariah, dimana BPRS seringkali ikut andil dalam proses berkembangnya usaha ekonomi mikro di Indonesia. Dilihat dari isu yang ada dari katadata.id, Mei 2019 yaitu bahwa pertumbuhan industri stabil, kinerja pembiayaan lembaga keuangan syariah melambat. Disini dikatakan bahwa sampai dengan Mei - 2019 merinci nilai pasar modal syariah hingga periode yang sama mencapai Rp727,08 triliun, IKNB sebesar Rp100,49 triliun, dan total asset perbankan sebesar Rp484,62 triliun. Padahal setahun sebelumnya, posisi akhir pertumbuhan industri keuangan sebesar $13,98 \%$ sekarang ada pada $11,25 \%$, telah terjadi penurunan sekitar 2,73\% pada pertumbuhan industri keuangan. Hal tersebut mempengaruhi market share dari perbankan yang hanya mencapai 5,85\% dari total keseluruhan industri perbankan (Sulmaihati F. , 2019).

\section{Grafik 1.1 Porsi Akad Pembiayaan di BPRS 2013-2018}

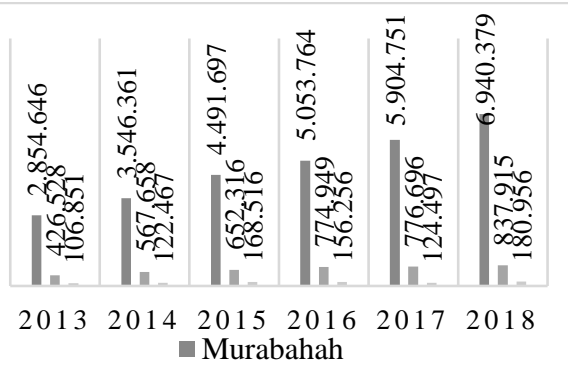

Sumber : Statistik Perbankan Syariah (OJK,2019)

Data di atas menunjukkan porsi pembiayaan berbasis bagi hasil yaitu musyarakah dan mudharabah masih rendah dibanding porsi pembiayaan berbasis jual beli atau murabahah. Pembiayaan musyarakah dan mudharabah termasuk kepada pembiayaan dengan akad Natural Uncertainty Contracts (NUC), karena tidak memberikan kepastian pengembalian atau keuntungan. Sehingga risiko kredit atau gagal bayar sering terjadi. Tidak menutup kemungkinan pada pembiayaan murabahah meskipun jelas pengembaliannya akan terjadi risiko kredit. Risiko kredit adalah risiko akibat kegagalan debitur dan atau pihak lain dalam memenuhi kewajiban kepada bank.

Non Performing Financing (NPF) Bank Pembiayaan Rakyat Syariah selalu mengalami kenaikan. Pada tahun 2014 ke 2015 mengalami kenaikan dari 7,89\% menjadi 8,20\%. Kemudian tahun 2016 dan 2017 kenaikan mencapai 1,05\% dari 8,63\% menjadi 9,68\%. Kenaikan paling tinggi terjadi pada tahun 2018 hingga mencapai 1,52\% menjadi sebesar 11,20\%. Selanjutnya, pada tahun 2019 mengalami penurunan nilai rasio menjadi sebesar 8,51\%. Adapun standar terbaik Non Performing Financing adalah kurang dari 5\% (BankIndonesia, 2011). Hal tersebut menunjukkan bahwa risiko kredit 
atau gagal bayar dalam proses pengembalian jumlah pembiayaan tidak sesuai dengan jangka waktu yang ditentukan, sehingga pembiayaan bermasalah atau Non Performing Financing (NPF) ada dan terus meningkat.

Adanya pembiayaan murabahah, musyarakah dan mudharabah yang bermasalah akan mengakibatkan hilangnya kesempatan memperoleh income (pendapatan) dari pembiayaan yang diberikan, sehingga hal tersebut dapat mengurangi perolehan laba dan berpengaruh buruk bagi profitabilitas bank (Dendawijaya, 2001).

Besar kecilnya kemampuan bank dalam menghasilkan laba dapat dilihat dari profitabilitas yang diperoleh. Risiko pembiayaan dapat mempengaruhi nilai profitabilitas yang didapatkan. Jika rasio Non Performing Financing tinggi, maka profitabilitas akan menurun dan tingkat bagi hasil menurun, selanjutnya apabila rasio Non Performing Financing turun, maka profitabilitas akan naik dan tingkat bagi hasil naik. Hal ini dikarenakan pendapatan yang diterima akan berkurang dan biaya untuk pencadangan penghapusan piutang akan bertambah yang dapat mengakibatkan laba menjadia menurun atau terjadi kerugian (Nofianti, 2015). Dengan ini penulis mengambil penelitian yang berjudul "Pengaruh Risiko Pembiayaan Akad Murabahah, Musyarakah dan Mudharabah Terhadap Profitabilitas BPRS di Indonesia tahun 2011-2019".

\section{TINJAUAN PUSTAKA}

\subsection{Profitabilitas}

Rasio profitabilitas merupakan rasio untuk menilai kemampuan perusahaan dalam mencari keuntungan. Rasio profitabilitas juga memberikan ukuran tingkat efektivitas dan efesiensi manajemen suatu perusahaan (Kasmir, 2015). Efektivitas dan efisiensi dapat dilihat dari laba yang dihasilkan dari kegiatan usahanya. Semakin tinggi nilai rasio maka dapat dikatakan bank tersebut rasio profitabilitasnya baik. Sebab kinerja keuangan menjadi baik, karena tingkat pengembalian (return) semakin besar. Indikator yang bisa digunakan untuk mengukur kinerja profitabilitas terdiri dari beberapa jenis yaitu, Grass Profit Margin (GPM), Net Profit Margin (NPM), Earning Per Share (EPS), Return on Equity (ROE), Return on Investment (ROI), dan Return on Assets (ROA). Return on Assets (ROA) merupakan rasio profitabilitas yang menunjukkan perbandingan antara laba (setelah pajak) dengan total asset bank, rasio ini menunjukkan tingkat efisiensi pengelolaan asset yang dilakukan oleh bank yang bersangkutan. ROA mampu mengukur kemampuan perusahaan manghasilkan keuntungan pada masa lampau untuk kemudian diproyeksikan di masa yang akan datang. Pengembalian atas total aktiva (ROA) dihitung dengan cara membandingkan laba bersih setelah pajak dengan total aktiva, seperti berikut: (Broetoseno, 2017)

$$
R O A=\frac{\text { Laba bersih setelah pajak }}{\text { Total Aktiva }} \quad x 100 \%
$$

Hasil perhitungan yang didapatkan bisa menyimpulkan seberapa besar pengembalian atas investasi yang dihasilkan oleh bank dengan membandingkan laba 
usaha dengan total asset. Maka, semakin besar rasio semakin besar kemampuan bank dalam menghasilkan laba. Seperti penelitian yang dilakukan oleh Munawir (2004) menyebutkan bahwa profitabilitas dapat menunjukkan kemampuan perusahaan dalam menghasilkan laba dan mempengaruhi kinerja perusahaan tersebut. Sedangkan penelitian yang dilakukan oleh Lyla Rahma Adyani (2012) menyebutkan Return on Assets merupakan rasio penting bagi bank karena ROA digunakan untuk mengukur efektivitas perusahaan dalam menghasilkan keuntungan dengan memanfaatkan aktiva yang dimilikinya.

\subsection{Pembiayaan Murabahah}

Murabahah adalah akad jual beli yang dilakukan ketika penjual menyatakan biaya perolehan barang, meliputi harga barang dan biaya lain yang dikeluarkan ketika memperoleh barang tersebut, beserta tingkat keuntungan (margin) yang diinginkan (Ascarya, 2011).

Menurut PSAK 102 tentang Akuntansi Murabahah, murabahah adalah akad jual beli barang dengan menyatakan harga perolehan dan keuntungan (margin) yang disepakati oleh penjual dan pembeli (Nabhan, 2008). Pelaksanaan akad murabahah biasa dilakukan untuk pembelian barang-barang investasi, kendaraan bermotor atau pada pembelian rumah. Penjualan tersebut dilakukan atas dasar cost-plus profit (Sudarsono, 2004)

Menurut penelitian yang dilakukan oleh Lukmanul Hakim (2017) mengemukakan bahwa 75\% kekayaan bank umum syariah merupakan hasil dari pembiayaan murabahah. Murabahah menjadi produk yang mendominasi dilembaga keuangan syariah, bahkan setiap tahunnya meningkat 55\% sampai dengan 59\% (Juliana F. S., 2019). Sementara itu, penelitian yang dilakukan di BMI Semarang pada tahun 1999, sekitar 78\% dari total pembiayaan adalah pembiayaan murabahah (Rahmawaty, 2007). Maka dapat disimpulkan bahwa pembiayaan murabahah merupakan pembiayaan metode utama yang digunakan di lembaga keuangan syariah.

\subsection{Pembiayaan Musyarakah}

Musyarakah merupakan akad kerjasama antara dua pihak atau lebih dalam suatu usaha dimana masing-masing pihak tersebut memberikan kontribusi dana (mal), dengan kesepakatan pembagian keuntungan dan risiko ditanggung bersama sesuai kesepakatan (Ridwan, 2007). Dalam pelaksanaan akad musyarakah terdapat mitra aktif dan mitra pasif, yang dimaksud mitra aktif adalah nasabah yang mengajukan pembiayaan dengan ketentuan dananya tetap sampai pada akhir masa akad. Sedangkan mitra pasif adalah pihak bank yang tidak ikut mengelola usaha secara langsung.

Dalam mengembangkan potensi dalam berwirausaha dibutuhkan pola bisnis yang prospektif dan berkeadilan melalui pola syirkah ini salah satunya (Juliana H. M., 2020). Penelitian yang dilakukan oleh Yunita Agza (2017) mengemukakan bahwa pembiayaan musyarakah berpengaruh negatif terhadap profitabilitas. Karena pembiayaan musyarakah memiliki risiko yang relatif tinggi dalam proses pengembaliannya. Sehingga, 
hal tersebut menyebabkan pembiayaan bermasalah pada akad musyarakah selalu bertambah.

\subsection{Pembiayaan Mudharabah}

Mudharabah berasal dari kata dharb, yang artinya berarti memukul atau berjalan. Mudharabah adalah bentuk kerjasama anatara dua pihak atau lebih, dimana salah satu pihak sebagai pemilik dana yang mempercayai pihak lain sebagai pengelola dananya, dengan tujuan mendapatkan keuntungan (Karim, 2010). Mudharabah didefinisikan sebagai akad kerjasama usaha antara dua pihak dimana pihak pertama (shahibul mal) menyediakan seluruh dana, sedangkan pihak kedua (mudharib) bertindak selaku pengelola, dan keuntungan dibagi diantara mereka sesuai kesepakatan sedangkan kerugian hanya ditanggung oleh pemilik dana. Kerugian akan ditanggung oleh pengelola dana apabila diakibatkan oleh kelalaian dari pengelola dana.

Pada penelitian sebelumnya yang dilakukan oleh Putri (2017) menunjukkan bahwa pembiayaan mudharabah berpengaruh negatif terhadap profitabilitas. Sejalan dengan penelitian yang dilakukan oleh Reinissa (2013) menyatakan bahwa pembiayaan mudharabah memiliki pengaruh negatif teradap ROA. Hal tersebut disebabkan oleh pembiayaan mudaharabah yang lebih berpengaruh terhadap ekuitas dibanding asset.

\subsection{Risiko Pembiayaan}

Menurut Karim (2010) menjelaskan bahwa risiko pembiayaan merupakan risiko yang disebabkan oleh adanya counterparty dalam memenuhi kewajibannya. Dalam bank syariah, risiko pembiayaan mencakup risiko terkait produk dan risiko terkait dengan pembiayaan korporasi. Berdasarkan PBI (Peraturan Bank Indonesia) No. 13/23/PBI/2011 tentang penerapan manajemen risiko untuk bank umum syariah dan unit syariah, risiko kredit merupakan akibat kegagalan nasabah atau pihak lain dalam memenuhi kewajiban kepada bank sesuai dengan perjanjian yang disepakati.

Pembiayaan bermasalah merupakan suatu peminjaman dana yang tertunda atau ketidak mampuan peminjam untuk mengembalikan dana atau kewajiban yang telah dibebankan kepadanya. Dengan timbulnya masalah atau risiko dari operasional perusahaanya, maka banyak debitur yang pembiayaannya bermasalah.

Sesuai dengan SE BI No. 9/24/Dpbs tanggal 30 Oktober 2007 tentang sistem penilaian kesehatan bank berdasarkan prinsip syariah Non Performing Financing atau pembiayaan bermasalah dirumuskan sebagai berikut:

$$
N P F=\frac{\text { Pembiayaan Bermasalah }(K L, D, M)}{\text { Total Pembiayaan }} \times 100 \%
$$

Rasio tersebut ditunjukkan untuk mengukur tingkat pembiayaan bermaslah yang ada di bank syariah. Apabila semkain tinggi maka semakin buruk rasio NPF perusahaan tersebut. Berikut adalah kriteria kesehatan Non Performing Financing (NPF) menurut Bank Indonesia: 
Tabel 1.1 Kriteria Kesehatan

\begin{tabular}{lll}
\hline No & Nilai NPF & Predikat \\
\hline 1 & $\mathrm{NPF}>2 \%$ & Sehat \\
2 & $2 \% \leq \mathrm{NPF}<5 \%$ & Sehat \\
3 & $5 \% \leq \mathrm{NPF}<8 \%$ & Cukup Sehat \\
4 & $8 \% \leq \mathrm{NPF}<12 \%$ & Kurang Sehat \\
5 & $\mathrm{NPF} \geq 12 \%$ & Tidak Sehat \\
\hline
\end{tabular}

Sumber: Bank Indonesia (2011)

Penelitian terdahulu yang dilakukan oleh Rokhmana (2012) mengemukakan bahwa produk investasi memiliki sifat yang senantiasa mendatangkan risiko, pembiayaan pun mengalami ketidakpastian atas pengembalian laba atau keuntungan dari dana

$\mathrm{H}_{1}$ : Adanya pengaruh tingkat risiko pembiayaan akad murabahah terhadap Return on Asset pada BPRS di Indonesia tahun 2011-2019.

Pembiayaan akan sangat berpengaruh terhadap profitabilitas, sehingga adanya tingkat risiko pembiayaan secara alami akan memberikan pengaruh terhadap pendapatan. Terutama pada pembiayaan murabahah yang digunakan untuk pembelian barang konsumtif, sehingga dapat mempengaruhi pembayaran nasabah dimasa mendatang.

Menurut penelitian Fahrul (2012) menunjukkan bahwa tingkat risiko pembiayaan murabahah memiliki pengaruh terhadap profitabilitas. Sejalan dengan penelitian Nurjanah (2016) menyatakan bahwa pembiayaan murabahah memiliki pengaruh positif terhadap Return on Asset. Penelitian yang dilakukan oleh Oktriani (2012) juga menunjukkan bahwa pembiayaan murabahah berpengaruh signifikan terhadap Return on Asset (ROA).

Dalam menekan tingkat NPF dengan cara berpedoman pada Standar Operasional dan Prosedur yang ditetapkan, juga menganalisis calon nasabah secara mendetail dan menyeluruh (Sudarlam, 2016). Berbeda dengan penelitian Mawaddah (2015) menyebutkan bahwa NPF tidak berpengaruh signifikan terhadap profitabilitas.

$\mathrm{H}_{2}$ : Adanya pengaruh tingkat risiko pembiayaan akad musyarakah terhadap Return on Asset pada BPRS di Indonesia tahun 2011-2019.

Musyarakah merupakan akad kerjasama yang banyak digunakan dalam pengembangan suatu proyek atau usaha. Sering ditemukan pembiayaan bermasalah ketika terjadi ketidakstabilan dari usaha tersebut. Menurut penelitian Sodiq (2015) pembiayaan musyarakah berpengaruh terhadap Return on Asset. Maka nisbah yang diperoleh akan mempengaruhi besarnya laba yang diperoleh bank syariah, dimana semakin tinggi pendapatan atau pembiayaan mudharabah yang diberikan bank untuk penyaluran dana. Maka semakin tinggi pula tingkat Return on Asset yang diperoleh bank. Sejalan dengan penelitian Refinaldy (2014) menunjukkan bahwa risiko pembiayaan musyarakah berpengaruh terhadap profitabilitas pada bank umum 
syariah. Hal ini mengartikan setiap kenaikan risiko pembiayaan musyarakah akan berdampak pada tingkat profitabilitas.

Selanjutnya penelitian Sari (2018) mengatakan pengaruh pembiayaan akad musyarakah tidak signifikan, maka setiap kenaikan pembiayaan musyarakah yang disalurkan akan diikuti kenaikan pada Return on Asset. Artinya risiko pembiayaan dapat diatasi oleh adanya bagi hasil dari pembiayaan lain, cadangan piutang yang besar, dan penempatan pada bank lain.

$\mathrm{H}_{3}$ : Adanya pengaruh tingkat risiko pembiayaan akad mudharabah terhadap Return on Asset pada BPRS di Indonesia tahun 2011-2019.

Risiko pembiayaan memiliki dampak pada kelancaran dan kemampuan bank untuk memperoleh profitabilitas (Refinaldy, 2014). Pengelolaan pembiayaan mudharabah dapat menghasilkan pendapatan berupa nisbah. Maka hal tersebut akan mempengaruhi laba yang diperoleh bank syariah, dimana semakin tinggi pendapatan atau pembiayaan mudharabah yang diberikan, akan semakin tinggi pula tingkat Return on Asset yang didapatkan bank tersebut (Sodiq, 2015). Sehingga tingkat risiko pembiayaanpun memiliki pengaruh dalam pencapaian keuntungan atau laba perusahaan.

Menurut penelitian Hidayah (2017) menunjukkan bahwa yang mempengaruhi turunnya profitabilitas dikarenakan ketidakjujuran nasabah atau asymetric information terkait keuntungan yang diperoleh. Sehingga pembiayaan akad mudharabah memiliki pengaruh yang negatif. Sejalan dengan penelitian Taudlikhul Afkar (2018) risiko pembiayaan akad mudharabah memiliki pengaruh dan tidak signifikan terhadap Return on Asset.

Kemudian pada penelitian Ria Nita Perdana (2016) mengemukakan bahwa tingkat risiko pembiayaan mudharabah memiliki pengaruh positif dan tidak signifikan terhadap profitabilitas. Apabila semakin banyak jumlah pembiayaan mudharabah yang disalurkan maka semakin tinggi Return on Asset yang dihasilkan oleh bank syariah. Penelitian yang dilakukan oleh Komariah (2017) menyebutkan bahwa pembiayaan mudharabah tidak berpengaruh terhadap profitabilitas, sehingga kenaikannya tidak mempengaruhi profitabilitas.

\section{METODE PENELITIAN}

Dalam penelitian ini terdapat variabel terikat yaitu Return on Asset $\left(Y_{1}\right)$, sedangkan variable bebasnya terdiri dari tingkat risiko pembiayaan murabahah $\left(X_{1}\right)$, tingkat risiko pembiayaan musyarakah $\left(X_{2}\right)$, dan tingkat risiko pembiayaan mudharabah $\left(X_{3}\right)$. Data penelitian diambil dari Statistik Perbankan Syariah OJK mulai tahun 2011-2019 pada Bank Pembiayaan Rakyat Syariah di Indonesia.

Model analisis dalam penelitian menggunakan metode Ordinary Least Square (OLS) dengan analisis linier berganda pada data time series. Sehingga spesifikasi model yang digunakan dalam penelitian ini adalah sebagai berikut:

$$
Y=\beta_{0}+\beta_{1} X_{1}+\beta_{2} X_{2}+\beta_{3} X_{3}+u
$$


Dimana:

Y $=$ Profitabilitas Return on Asset BPRS di Indonesia

$\beta_{0}=$ Konstanta

$\beta_{1-2}=$ Koefisien regresi

$X_{1}=$ NPF Pembiayaan Murabahah

$X_{2}=$ NPF Pembiayaan Musyarakah

$X_{3}=$ NPF Pembiayaan Mudharabah

$u \quad=$ Variabel penganggu

Untuk menguji hipotesis yang diajukan, penelitian ini menggunakan analisis regresi linier berganda, dengan Uji - $t$ dan Uji F. Serta digunakan juga analisis Uji Asumsi Klasik antara lain: Multikolinearitas, Heteroskedastisitas, dan Autokorelasi.

\section{HASIL DAN PEMBAHASAN}

Dari hasil olah data menggunakan Eviews 10 maka diperoleh persamaan sebagai berikut:

ROA=3.333509-20.91331 NPF MURABAHA +0.851621 NPF MUSYARAKAH+0.000174 NPF MUDHARABAH+e

Persamaan regresi diatas dapat dijelaskan sebagai berikut:

a. Konstanta sebesar 3.333509 artinya apabila nilai NPF Murabahah, NPF Musyarakah, dan NPF Mudharabah sama dengan 0 maka variabel ROA akan meningkat sebesar 3.333509\%.

b. Variabel NPF Murabahah memiliki nilai -20.91331 artinya, apabila terjadi kenaikan variabel NPF Murabahah sebesar 1\% maka variabel ROA mengalami penurunan sebesar 20.91331 \% dengan asumsi variabel lain adalah konstan atau ceteris paribus.

c. Variabel NPF Musyarakah memiliki nilai 0.851621 artinya, apabila terjadi kenaikan variabel NPF Musyarakah sebesar 1\% maka variabel ROA akan mengalami peningkatan sebesar $0.851621 \%$ dengan asumsi variabel lain adalah konstan atau ceteris paribus.

Variabel NPF Mudharabah memiliki nilai 0.000174 artinya, apabila terjadi kenaikan variabel NPF Mudharabah sebesar 1\% maka variabel ROA akan mengalami peningkatan sebesar $0.000174 \%$ dengan asumsi variabel lain adalah konstan atau ceteris paribus.

Pengujian hipotesis dilakukan untuk mengetahui ada tidaknya pengaruh secara nyata hubungan variable bebas terhadap variable terikat baik secara simultan maupun secara parsial. Pengujian hipotesis menggunakan Uji F dan Uji t. Uji F merupakan pengujian untuk mengetahui ada tidaknya pengaruh secara simultan antar variable bebas dengan variable terikat, dapat dilihat pada tabel 1.2 sebagai berikut:

\begin{tabular}{lc} 
& \multicolumn{2}{c}{ Tabel 1.2 Uji F } \\
\hline F-statistic & 11.48115 \\
Prob(F-statistic) & 0.011114 \\
\hline \multicolumn{2}{l}{ Sumber: Data diolah (2020) }
\end{tabular}


Hasil Uji F menunjukan bahwa F-statistic (11.48115) lebih besar dari pada F tabel $(4,76)$ dan probabilitasnya $(0,011114)$ lebih kecil dari tingkat signifikansi $\alpha=0,05$. Maka Tingkat Risiko Pembiayaan Murabahah, Musyarakah, dan Mudharabah secara bersama-sama berpengaruh terhadap Profitabilitas yang diproyeksikan dengan Return on Asset.

Sedangkan, Uji t merupakan pengujian untuk mengetahui ada tidaknya pengaruh secara parsial antara masing-masing variable bebas terhadap variable terikat. Jika $\mathrm{t}$ hitung > t table maka $H_{a}$ diterima dan menolak $H_{0}$.

\section{Tabel 1.3 Hasil Regresi Linier Berganda}

\begin{tabular}{llllll}
\hline Var & Coefficient & Std. Error & t-Statistic & Prob. & Keputusan \\
$\mathrm{X}_{1}$ & -20.91331 & 3.864575 & -5.411542 & 0.0029 & Menolak Ho \\
$\mathrm{X}_{2}$ & 0.851621 & 0.430646 & 1.977542 & 0.1049 & Menolak Ho \\
$\mathrm{X}_{3}$ & 0.00174 & $6.19 \mathrm{E}-05$ & 2.804679 & 0.0378 & Menolak Ho \\
\hline
\end{tabular}

Sumber: Data diolah (2020)

Berdasarkan pada tabel diatas, dapat dijelaskan bahwa nilai t hitung (-5.411542) lebih besar dari t tabel 1,94318 yang berarti menerima $H_{a}$ dan menolak $H_{0}$. Kemudian tingkat probabilitas sebesar 0,0029 lebih kecil dari $\alpha=0,05$, sehingga dapat disimpulkan bahwa $X_{1}$ (NPF Murabahah) berpengaruh dan signifikan terhadap $Y$ (Return on Asset) dengan arah negatif. Hal ini menunjukkan bahwa setiap kenaikan variabel NPF murabahah sebesar $1 \%$ maka variabel Return on Asset akan mengalami penurunan sebesar $0,20 \%$. Hasil penelitian ini menerima $H_{a}$ dalam hipotesis, karena dalam hasil penelitian tingkat risiko pembiayaan (NPF) akad murabahah berpengaruh negatif dan siginifikan terhadap Return on Asset. Risiko pembiayaan yang muncul dari pembiayaan murabahah disebabkan oleh gagal bayar dan mempengaruhi keuntungan yang akan diperoleh oleh bank.

Hasil penelitian ini sejalan dengan beberapa penelitian terdahulu, seperti penelitian yang dilakukan Siti Musyarafah (2016) menunjukkan bahwa risiko pembiayaan murabahah dan mudharabah berpengaruh negatif terhadap profitabilitas Return on Asset. Hasil yang sama ditunjukkan oleh penelitian Komariah (2016) menyebutkan bahwa pembiayaan murabahah berpengaruh signifikan terhadap profitabilitas. Hal tersebut dikarenakan pembiayaan murabahah lebih banyak disalurkan pada barang konsumtif, sehingga mempengaruhi pengembalian kepada bank. Karena Return on Asset merupakan rasio yang mampu mengukur kemampuan perusahaan dalam menghasilkan keuntungan.

Selanjutnya, menunjukkan bahwa nilai thitung (1.977542) lebih besar dari t tabel 1,94318 yang berarti menolak $H_{0}$ dan menerima $H_{a}$. Kemudian tingkat probabilitas sebesar 0,1049 lebih besar dari $\alpha=0,05$, sehingga dapat disimpulkan bahwa $X_{2}$ (NPF Musyarakah) tidak berpengaruh signifikan terhadap $Y$ (Return on Asset) dengan arah positif. Hal ini menunjukkan bahwa setiap kenaikan variabel NPF musyarakah sebesar 1\% maka variabel Return on Asset akan mengalami peningkatan sebesar 0,85\%. Hasil penelitian ini menolak $H_{0}$ dalam hipotesis, karena dalam hasil penelitian tingkat risiko 
pembiayaan (NPF) akad musyarakah berpengaruh positif dan tidak signfikan terhadap Return on Asset.

Hasil penelitian ini sejalan dengan penelitian yang dilakukan Aditya (2016) yang menyatakan bahwa tingkat risiko pembiayaan musyarakah berpengaruh positif dan tidak signifikan terhadap Return on Asset. Namun bertentangan dengan beberapa penelitian terdahulu, seperti penelitian yang dilakukan Cut Afrianandra dan Evi Mutia (2014) menunjukkan bahwa risiko pembiayaan musyarakah berpengaruh positif terhadap profitabilitas Return on Asset. Kemudian hasil yang sama ditunjukkan oleh penelitian Maya Kiswati (2017) menyebutkan bahwa pembiayaan musyarakah berpengaruh positif signifikan terhadap profitabilitas. Terdapat beberapa hal yang dapat menyebabkan risiko pembiayaan musyarakah berpengaruh positif namun tidak signifikan, diantaranya karena dalam proses pembiayaan musyarakah dilakukan pengawasan proyek usaha sehingga diperlukan biaya tambahan untuk pengawasan tersebut. Karena pembiayaan musyarakah memiliki risiko yang relatif tinggi, maka bank syariah menekan risiko tersebut dengan memperkerjakan para teknisi dan manajemen ahli untuk mengevaluasi proyek usaha nasabahnya (Muhammad, 2005). Selain itu, pada pembiayaan musyarakah bagi hasil ditentukan diawal saat akad akan dilakukan dan pembiayaan yang disalurkan dalam jumlah besar akan diikuti dengan risiko yang besar pula. Sehingga apabila terjadi kerugian pada pembiayaan musyarakah, bank tidak akan mengalami kerugian karena bagi hasil yang didapatkan oleh bak dapat menutupi risiko yang akan terjadi. (Mutia, 2014)

Adapun pada pengujian selanjutnya, menunjukkan bahwa nilai $t$ hitung (2.804679) lebih besar dari t tabel 1,94318 yang berarti menolak $H_{0}$ dan menerima $H_{a}$. Kemudian tingkat probabilitas sebesar 0,0378 lebih kecil dari $\alpha=0,05$, sehingga dapat disimpulkan bahwa $X_{3}$ (NPF Mudharabah) berpengaruh dan signifikan terhadap $Y$ (Return on Asset) dengan arah positif. Hal ini menunjukkan bahwa setiap kenaikan variabel NPF mudharabah sebesar 1\% maka variabel Return on Asset akan mengalami peningkatan sebesar $0,000174 \%$. Hasil penelitian ini menolak $H_{0}$ dalam hipotesis, karena dalam hasil penelitian tingkat risiko pembiayaan (NPF) akad mudharabah berpengaruh positif dan signfikan terhadap Return on Asset.

Hasil penelitian ini sejalan dengan penelitian yang dilakukan oleh Jaurino dan Renny Wulandari (2017) menunjukkan bahwa pembiayaan mudharabah berpengaruh terhadap profitabilitas. Namun bertentangan dengan penelitian Taudlikhul Afkar (2018) risiko pembiayaan akad mudharabah memiliki pengaruh dan tidak signifikan terhadap Return on Asset. Kemudian pada penelitian Ria Nita Perdana (2016) mengemukakan bahwa tingkat risiko pembiayaan mudharabah memiliki pengaruh positif dan tidak signifikan terhadap profitabilitas. Apabila semakin banyak jumlah pembiayaan mudharabah yang disalurkan maka semakin tinggi Return on Asset yang dihasilkan oleh bank syariah. Dapat disimpulkan bahwa pembiayaan mudharabah termasuk pembiayaan yang memiliki risiko tinggi dan menggunakan akad Profit Sharing. Sehingga, pembiayaan mudharabah merupakan akad kerja sama dimana ketika terjadi 
kerugian yang akan menanggung seluruh kerugian adalah bank syariah selama pengelola tidak melakukan kesalahan (Ascarya, 2011).

Koefisien determinasi mengukur sejauh mana kemampuan model dalam menjelaskan variasi variabel dependen. Dapat diihat pada tabel 1.4 sebagai berikut:

\section{Tabel 1.4 Koefisien Determinasi}

$\frac{\text { Adjusted R-squared } \quad 0.797178}{\text { Sumber: Data diolah (2020) }}$

Berdasarkan tabel 1.4, yang merupakan analisis regresi data panel dengan model regresi linier berganda menunjukkan Adjusted R-squared sebesar 0,797178. Hal tersebut menunjukkan bahwa 79,7178\% Y (Return on Asset) dapat dijelaskan oleh variabel independen yaitu $X_{1}$ (NPF Murabahah), $X_{2}$ (NPF Musyarakah), dan $X_{3}$ (NPF Mudharabah). Sedangkan sisanya $(100 \%-79,7178 \%=20,2822 \%)$ dijeaskan oleh variabel-variabel lain diluar model yang tidak dimasukkan kedalam penelitian.

\section{PENUTUP}

Berdasarkan data BPRS dari tahun 2013-2018 menunjukkan adanya rasio NonPerforming Financing yang tinggi dan ROA yang fluktuatif dengan arah menurun, mengindikasikan bahwa hal ini dapat mempengaruhi tingkat kemampuan perusahaan dalam memperoleh laba yang optimal. Penelitian ini bertujuan untuk mengetahui pengaruh risiko pembiayaan (NPF) Murabahah, risiko pembiayaan (NPF) Musyarakah, dan risiko pembiayaan (NPF) Mudharabah terhadap Return on Asset (ROA) BPRS di Indonesia Tahun 2011-2019. Hasil dari penelitian ini menunjukkan bahwa pertama, tingkat risiko pembiayaan akad Murabahah berpengaruh dan signifikan terhadap Return on Asset dengan arah yang negatif, hal ini sesuai dengan gambaran umum bahwa pembiayaan murabahah berada pada angka yang relatif tinggi. Maka, semakin banyak dana yang disalurkan oleh perusahaan, maka semakin banyak pula laba yang dihasilkan, demikian sebaliknya. Kedua, tingkat risiko pembiayaan Musyarakah tidak berpengaruh signifikan, hal ini dapat dikarenakan dalam proses pembiayaan musyarakah terdapat pengawasan proyek usaha sehingga diperlukan biaya tambahan untuk pengawasan tersebut. Selain itu, pada pembiayaan musyarakah bagi hasil ditentukan diawal saat akad akan dilakukan dan pembiayaan yang disalurkan dalam jumlah besar akan diikuti dengan risiko yang besar pula. Sehingga apabila terjadi kerugian pada pembiayaan musyarakah, bank tidak akan mengalami kerugian karena bagi hasil yang didapatkan oleh bank dapat menutupi risiko yang akan terjadi. Ketiga, risiko pembiayaan akad Mudharabah berpengaruh dan signifikan terhadap Return on Asset dengan arah yang positif, hal ini dikarenakan BPRS merupakan lembaga keuangan yang bergerak di bidang sektor riil dan kebijakan pembiayaan dana mudharabah lebih banyak dislaurkan pada sektor usaha mikro kecil dan menengah (UMKM), sehingga tahan terhadap ekonomi global maupun inflasi. Selanjutnya, akad pembiayaan mudharabah menggunakan prinsip Profit Sharing sehingga, pembiayaan mudharabah merupakan akad kerja sama dimana ketika terjadi kerugian yang akan 
menanggung seluruh kerugian adalah bank syariah selama pengelola tidak melakukan kesalahan. Hal tersebut dapat mempengaruhi perolehan keuntungan yang didapatkan bank syariah. Oleh karena itu, penelitian yang dilakukan memberi kesimpulan bahwa, secara parsial, risiko pembiayaan berpengaruh terhadap profitabilitas perusahaan. Penelitian ini memberi kontribusi terhadap literatur penelitian dan memperkuat teori bahwa risiko pembiayaan memiliki pengaruh terhadap profitabilitas. Selain itu, implikasi dari penelitian ini bagi perusahaan yaitu untuk lebih bisa memitigasi risiko pembiayaan bermasalah, salah satunya dengan lebih menyeleksi fasilitas pembiayaan terhadap nasabah. Bagi regulator, diharapkan adanya kebijakan yang mampu menekan rasio NPF pada BPRS agar tidak mempengaruhi kinerja keuangan perusahaan serta market share perbankan syariah.

\section{DAFTAR PUSTAKA}

Adrian, S. (2009). Perbankan Syariah Tinjauan dari Beberapa Segi Hukum. Jakarta: Ghalia Indonesia.

Ahmed, T. K. (n.d.). Manajemen Risiko . 51.

Antonio, M. S. (2001). Bank Syariah: Dari Teori ke Praktik. Jakarta: Gema Insani.

Arifin, V. R. (2010). Islamic Banking: Sebuah Teori, Konsep, dan Aplikasi. Jakarta: Bumi Aksara.

Ascarya. (2011). Akad Eु Produk Bank Syariah. Jakarta: Rajawali Pers.

Broetoseno, O. (2017). Pengaruh net profit margin (NPM), return on asset (ROA), return on equity (ROE) terhadap harga saham pada perusahaan food and beverages yang terdaftar di BEI periode 2012-2015.

Darmawi, H. (2009). Manajemen Risiko. Jakarta: Bumi Aksara.

Fahrul. (2012). Pengaruh Tingkat Risiko Pembiayaan Musyarakah dan Murabahah terhadap tingkat Profitabilitas Bank Syariah (Studi Pada Bank Aceh Syariah Cabang Banda Aceh). Jurnal Akuntansi ISSN 2302-0164.

Friyanto. (2013). PEMBIAYAAN MUDHARABAH, RISIKO DAN PENANGANANNYA (Studi Kasus Pada Bank BTN Kantor Cabang Syariah Malang). Jurnal Manajemen dan Kewirausahaan, Vol. 15 No. 2 Hal. 114 - 117.

Ghozali, I. (2011). Aplikasi Analisis Multivariate Dengan Program SPSS. Semarang: Badan Penerbit Universitas Diponegoro.

Hadi, A. C. (2011). PROBLEMATIKA PEMBIAYAAN MUDHÂRABAH DI PERBANKAN SYARIAH INDONESIA. Al - Iqtishad, Vol. III No. 2 Hal. 200.

Juliana, F. S. (2019). Sharia Compliance: Case Study on Murabahah at BMT ItQan. ICIEBP 2nd, 914.

Juliana, H. M. (2020). Syirkah:Implementation of Fresh Water Fishing Fishery. TSARWATICA.

Jumi Atika, S. M. (2015). PRINSIP KEHATI-HATIAN DALAM PENCEGAHAN. AtTijaroh, Vol. No.2 Hal. 24 - 28.

Karim, A. (2010). Bank Islam: Analisis Fiqih dan Keuangan. Jakarta: PT. Raja Grafindo. Kasmir. (2015). Analisis Laporan Keuangan. Jakarta: PT. Raja Grafindo Persada. 
Kusnanto, H. (Juli 2018). Pengaruh Pembiayaan Murabahah dan Non Performing Financing (NPF) Terhadap Profitabilitas Bank Syariah. 13.

Latifah, F. S. (2015). Pengaruh Risiko Pembiayaan Terhadap Profitabilitas Pada Bank Umum Syariah Periode 2009-2013.

Lukmanul Hakim, A. A. (2017). Pembiayaan Murabahah Pada Perbankan Syariah Dalam Perspektif Hukum di Indonesia. AL-URBAN, Jurnal Ekonomi Syariah dan Filantropi Islam .

Lyla Rahma Adyani, D. R. (2012). Analisis Faktor-Faktor Yang Mempengaruhi Profitabilitas (ROA).

Mardani. (n.d.). Aspek Hukum Lembaga Keuangan .

Muhammad. (2005). Bank Syariah Problem dan Proses Perkembangan di Indonesia. Yogyakarta: Graha Ilmu.

Munawir. (2004). Analisis Laporan Keuangan. Yogyakarta: Liberty.

Mutia, C. A. (2014). Pengaruh RisikoPembiayaan Musyarakah dan Murabahah Terhadap Profitabilitas Bank Umum Syariah di Indonesia. Jurnal Dinamika Akuntansi dan Bisnis Vol. 1 No.2.

Nabhan, F. (2008). Pengantar Akuntansi Bank Syariah. Yogyakarta: Lumbung Ilmu.

Nofianti, N. (2015). Analisis Pengaruh Return on Asset (ROA), Biaya Operasional terhadap Pendapatan Operasional (BOPO), Suku Bunga, Financing to Deposit Ratio (FDR), dan Non Peforming Financing (NPF) terhadap Tingkat Bagi Hasil, Deposit Mudharabah BUS Tahun 2011-2013. Jurnal Bisnis dan Manajemen Vol. 5, No. 1,71 .

Oktriani, Y. (2012). Pengaruh pembiayaan musyarakah, mudharabah dan murabahah terhadap profitabilitas (studi kasus pada PT. Bank Muamalat Indonesia, Tbk.). Jurnal Jurusan Akuntansi Fakultas Ekonomi. Universitas Siliwangi.

Primasatya, A. (2014). PENANGANAN PEMBIAYAAN MUDHARABAH BERMASALAH DI KOPERASI SYARIAH KANINDO JATIM. Jurnal Ilmiah, Hal. 7.

Putri, F. L. (2017). Pengaruh Pembiayaan Mudharaah terhadap Profitabilitas Bank Syariah. Jurnal Pendidikan Akuntansi dan Keuangan.

Rahmawaty, A. (2007). Tinjauan Kritis Produk Murabahah dalam Perbankan Syariah di Indonesia. Jurnal Ekonomi Islam La_Riba.

Refinaldy, A. (2014). Pengaruh Tingkat Risiko Pembiayaan Musyarakah dan Pembiayaan Mudharabah Terhadap Tingkat Profitabilitas Bank Syariah.

Reinissa. (2013). Pengaruh Pembiayaan Mudharabah,Musyarakah dan Murabahah Terhadap Profitabilitas Bank Syariah Mandiri . Jurnal Ilmiah.

Ridwan, M. (2007). Konstruksi Bank Syariah Indonesia. Yogyakarta: Pustaka.

Rokhmana, S. N. (2012). Analisis Pengaruh Risiko Pembiayaan terhadap Profitabilitas.

Rosmalinda, U. (2015). STUDI KRITIK PRINSIP KEHATI-HATIAN DALAM PERSPEKTIF PENCEGAHAN PEMBIAYAAN BERMASALAH PADA BANK SYARIAH. AKUISISI, Vol. 11 No. 2 Hal. 29. 
118 Silvia Isfiyanti, Rozmita Dewi Yuniarti dan Rumaisah Azizah Al Adawiyah

Sodiq, E. C. (2015). Pengaruh Pendapatan Mudharabah dan Musyarakah Terhadap Profitabilitas (ROA) Bank Syariah Mandiri Periode 2006-2014. Jurnal Ekonomi Syariah, Vol. 3 No. 1, 28-47.

Suhartatik N, K. R. (2013). Determinan Financing to Deposit Ratio (FDR) Perbankan Syariah di Indonesia (2008-2012). Jurnal Ilmu Manajemen, 1179.

Sulmaihati, F. (2019). Pertumbuhan Industri Keuangan Syariah Melambat. Katadata.id.

Sulmaihati, F. (2019). Pertumbuhan Industri Keuangan Syariah Melambat. Jakarta: Katadata.id.

Usman, R. (2012). Aspek Hukum Perbankan Syariah di Indonesia. Jakarta: Sinar Grafika.

Yunita Agza, D. (2017). Pengaruh Pembiayaan Murabahah, Musyarakah dan Biaya Transaksi Terhadap Profitabilitas Bank Pembiayaan Rakyat Syariah. Iqtishadia. 